\title{
Pemurnian Silikon (Si) Hasil Reduksi Silika dari Fly Ash Batubara
}

\author{
(Purification of Silicon from Silica Reduction Product of Coal Fly Ash)
}

\author{
Novita Andarini, Tanti Haryati, Rika Yulianti \\ Jurusan Kimia, Fakultas Matematika dan Ilmu Pengetahuan Alam, Universitas Jember (UNEJ) \\ Jln. Kalimantan 37, Jember 68121 \\ E-mail:novita.fmipa@unej.ac.id
}

\begin{abstract}
Abstrak
Fly ash merupakan limbah hasil pembakaran batubara yang mengandung beberapa senyawa kimia yang dapat dimanfaatkan.. Salah satu senyawa kimia dengan persentase tinggi di dalam fly ash adalah senyawa silika $\left(\mathrm{SiO}_{2}\right)$. Penelitian ini bertujuan untuk mendapatkan silikon murni hasil dari reduksi silika dari fly ash batubara. Silika diperoleh dengan metode ekstraksi yaitu dengan menggunakan $\mathrm{NaOH} 3 \mathrm{M}$ dan $\mathrm{HCl} 1 \mathrm{M}$, dilanjutkan dengan pemurnian silika menggunakan $\mathrm{HCl} 37 \%$. Silika murni yang diperoleh kemudian direduksi menggunakan metode metalotermal dengan logam magnesium. Komposisi massa silika dan magnesium yang digunakan dioptimasi dengan empat variasi perbandingan massa silika:magnesium masingmasing $1: 0,8 ; 1: 1,5 ; 1: 2$ dan 1:2,5. Produk optimum hasil dari proses reduksi kemudian dimurnikan menggunakan $150 \mathrm{~mL}$ $\mathrm{HCl} 2 \mathrm{M}$ lalu dipanaskan pada suhu $80^{\circ} \mathrm{C}$ sambil distirer selama 3 jam. Hasil analisa XRF (X-Ray fluorescence) menunjukkan persentase kadar silika yang diperoleh dari proses ekstraksi yaitu 79,72\% dan meningkat kadar kemurniannya menjadi 93,76\% setelah dilakukan pemurnian. Karakterisasi produk dari reaksi reduksi silika oleh magnesium menggunakan XRD dengan program software Match 3 secara keseluruhan terhadap semua variasi massa silika:magnesium menunjukkan bahwa silikon yang dihasilkan hanya diperoleh pada variasi silika:magnesium 1:0,8 yaitu sebanyak 4,8\%. Hal ini ditunjukkan dengan munculnya puncak 2 theta pada titik $42.77^{\circ}, 48.430$ dan $78.39^{\circ}$. Kemurnian silikon kemudian meningkat menjadi $5,6 \%$ setelah dilakukan pemurnian.
\end{abstract}

Kata Kunci: fly ash, pemurnian, reduksi, silika, silikon

\begin{abstract}
Fly ash is a coal combustion waste which contains of several chemical compounds that can be utilized. One of them that contains a high percentage is a silica compound (SiO2). This study aims to obtain a pure silicon form processed with the reduction of silica from fly ash coal. This silica is produced by an extraction method using $\mathrm{NaOH} 3 \mathrm{M}$ dan $\mathrm{HCl} 1 \mathrm{M}$, continued by purifying the silica using $\mathrm{HCl} 37 \%$. Then the pure silica is reduced by a metallothermal method using magnesium metal. The mass composition of silica and magnesium being used is optimized by four variations of silica and magnesium mass ratio, they are 1:0,8; 1:1,5;1:2 and 1:2,5. Then the optimum product resulting from the reduction is purified by $150 \mathrm{~mL} \mathrm{HCl} 2 \mathrm{M}$ while it is heated at $80^{\circ} \mathrm{C}$ and stirred for 3 hours. The XRF (X-Ray fluorescence) analysis showed that the percentage of silica content from the extraction process was $79.72 \%$ and increase to $93,76 \%$ after the purification process. The characterization of product from silica reduction reaction by magnesium is using XRD (X-Ray diffraction) with the Match 3 software program as a whole program to the all mass variations of silica:magnesium showed that the silicon production is only produced on silica:magnesium variation 1;0,8 is as much as 4,8\%. This condition is indicated by the appearance of 2 theta peaks at the point $42.77^{\circ}, 48.43^{\circ}$ and $78.39^{\circ}$. Finally the silicon purity is increased to $5.6 \%$ after purification.
\end{abstract}

Keywords: fly ash, purification, reduction, silica, silicon

\section{PENDAHULUAN}

Fly ash adalah abu yang dihasilkan dari pembakaran batubara. Jumlah substansi kimia yang terkandung dalam fly ash melimpah dan memiliki potensi pemanfaatan yang besar, salah satunya adalah silika, sehingga peneliti bermaksud untuk mengisolasinya dan dilanjutkan dengan adanya perlakuan untuk mendapatkan bentuk silikon dengan kemurnian tinggi. Penelitian tentang isolasi dan pemurnian silikon telah banyak dilakukan yang berasal dari abu sekam padi dan pasir. Isolasi silikon yang berasal dari fly ash batubara sudah pernah dilakukan tetapi tidak disertai dengan pemurnian, sehingga penelitian tentang hal tersebut perlu dilakukan. Hal ini berdasarkan pada manfaat silikon yang dapat digunakan dalam kehidupan sehari-hari.
Isolasi silikon dapat diawali dengan mengekstraksi silika dari fly ash dan proses yang dapat dilakukan untuk mendapatkan kemurnian silika yang tinggi dilakukan proses leaching asam menggunakan $\mathrm{HCl}$ 3\% terhadap sampel fly ash terlebih dahulu dengan tujuan untuk meminimalisir pengotor oksida logam [1]. Kondisi optimum metode presipitasi pada ekstraksi silika telah dilakukan oleh Retnosari [2] yang menyatakan bahwa $\mathrm{NaOH}$ dengan konsentrasi 3M merupakan kondisi terbaik dalam menghasilkan silika dengan jumlah banyak, dan menurut Fatony asam yang paling efektif digunakan untuk leaching dalam ekstraksi silika adalah $\mathrm{HCl}$ daripada $\mathrm{H}_{2} \mathrm{SO}_{4}$ [3]. Metode reduksi silika yang digunakan pada penelitian ini adalah metode metalotermal sederhana dengan pereduksi 
magnesium. Alasan pertama penggunaan magnesium didasarkan pada diagram Elliangham yang menunjukkan bahwa magnesium merupakan logam aktif yang dapat digunakan sebagai agen pereduksi. Alasan kedua penggunaan magnesium juga karena produk reaksi yang dihasilkan selain silikon dapat dengan mudah dihilangkan dengan cara pencucian asam (leaching) [4]. Metode lain yang dapat digunakan untuk mendapatkan silikon dari silika adalah dengan metode elektrolitik, namun metode ini harus dilakukan pada sistem cryolite yang membutuhkan suhu $1000^{\circ} \mathrm{C}$. Silikon yang dihasilkan oleh Grjotheim [5] dengan metode elektrolitik adalah silikon alloy, sehingga peneliti lebih memilih untuk menggunakan metode metalotermal yang lebih mudah dan tidak membutuhkan suhu yang tinggi serta dapat menghasilkan silikon dalam bentuk murni.

Beberapa metode pemurnian silikon juga yang berasal dari beberapa sampel sudah dilakukan, diantaranya adalah memurnikan silikon yang berasal dari silika fume menghasilkan kemurnian dengan kadar 99,1\%. Teknik pemurniannya menggunakan tiga macam asam dalam proses leaching yaitu asam klorida, asam asetat dan asam fluorida [6]. Adjiantoro melakukan pemurnian juga pada silikon menggunakan pelarutan kimia dan menghasilkan kemurnian silikon tertinggi dengan pelarut HF. Kemurnian silikon yang dihasilkan mencapai $80,90 \%$ dan sampel yang digunakan adalah MG-Si [7]. Sitorus mengisolasi silikon dari pasir kuarsa dan dilanjutkan dengan pemurnian menggunakan leaching menghasilkan silikon dengan kemurnian 84,0 \% [8]. Berdasarkan penelitian terdahulu maka dilakukan pemurnian silikon pada penelitian ini menggunakan metode leaching asam [6] dengan optimalisasi kondisi reaksi pada proses isolasi silikon dari fly ash dengan variasi komposisi silika/Mg 1:0,8; 1:1,5 ; $1: 2 ; 1: 2,5$. Hasil pemurnian dikarakterisasi menggunakan XRD ( $x$-Ray Diffraction) dengan program software Match 3.

\section{METODE PENELITIAN}

Pelaksanaan penelitian di Laboratorium Kimia Organik dan Laboratorium Kimia Dasar Jurusan Kimia Fakultas Matematika dan Ilmu Pengetahuan Alam Universitas Jember, Laboratorium Biosain Politeknik Negeri Jember, Laboratorium Kimia Dasar Universitas Negeri Yogyakarta dan Laboratorium MIPA terpadu FMIPA Universitas Sebelas Maret. Penelitian ini dilakukan mulai bulan Mei tahun 2016 sampai bulan Maret 2017.

\section{Peralatan}

Peralatan yang digunakan dalam penelitian meliputi cawan porselen, beaker glass $1000 \mathrm{~mL}$, beaker glass 500 $\mathrm{mL}$, beaker glass $150 \mathrm{~mL}$, gelas ukur $100 \mathrm{~mL}$, labu ukur $500 \mathrm{~mL}$, labu ukur $250 \mathrm{~mL}$, labu ukur $100 \mathrm{~mL}$, desikator, labu leher tiga, corong, $\mathrm{pH}$ meter Digital, termometer, hot plate stirer, anak stirer, oven, Heraeus furnace, kertas saring whatman no.41, kertas saring, mortar, neraca analitik, spatula, pipet tetes, pengaduk, penjepit, XRF tipe Bruker S2 Ranger dan XRD tipe Rigaku Miniflex600 dan software XRD Match 3.

\section{Bahan}

Bahan yang digunakan dalam penelitian adalah sampel berupa abu terbang (fly ash) yang berasal dari limbah PLTU di kecamatan Paiton kabupaten Probolinggo, magnesium (merck), $\mathrm{NaOH}$ (merck), $\mathrm{AgNO}_{3}, \mathrm{HCl}(37 \%)$ dan akuades.

\section{Prosedur}

\section{a. Preparasi sampel}

Diambil sampel abu terbang (fly ash) yang diambil dari PLTU Paiton-Probolinggo sebanyak 200 gram dan direndam dalam air panas selama 2 jam, kemudian hasil preparasi dianalisa menggunakan XRF [10].

\section{b. Pengasaman}

Pengasaman dilakukan dengan mengambil 25 gram sampel fly ash hasil preparasi kemudian ditambah dengan $500 \mathrm{~mL} \mathrm{HCl} \mathrm{3 \%} \mathrm{menggunakan} \mathrm{labu} \mathrm{leher} \mathrm{tiga.} \mathrm{Campuran}$ tersebut direfluks selama 2 jam, setelah itu larutan disaring dan residu dicuci dengan akuades panas hingga bersifat netral menggunakan $\mathrm{pH}$ universal. Residu dikeringkan di dalam oven pada suhu $100^{\circ} \mathrm{C}$ selama 24 jam. Hasil dari pengovenan akan menghasilkan serbuk fly ash yang digunakan untuk proses ekstraksi silika [8].

\section{c. Ekstraksi Silika}

Sampel hasil pengasaman kemudian ditambahkan ke dalam $150 \mathrm{~mL} \mathrm{NaOH}$ dengan konsentrasi $3 \mathrm{M}$. Pengadukan dilakukan dengan kecepatan $150 \mathrm{rpm}$ menggunakan magnetic stirrer pada suhu sekitar $65-70^{\circ} \mathrm{C}$ selama \pm 3 jam. Sampel kemudian disaring dengan kertas saring whatman no.41 dan diperoleh residu serta filtrat. Filtrat yang mengandung silika ditampung dan ditambah dengan $\mathrm{HCl} 1$ M sampai $\mathrm{pH}$ 7. Hasil yang diperoleh kemudian didiamkan selama 18 jam dan endapan yang diperoleh dipisahkan dan dicuci dengan akuades panas. Endapan kemudian dikeringkan dalam oven pada suhu $100^{\circ} \mathrm{C}$ selama 4 jam untuk menghilangkan air [9]. Analisa kadar silika hasil ekstraksi kemudian dianalisis menggunakan XRF.

\section{d. Pemurnian Silika}

Sebanyak 10 gram sampel silika hasil ekstraksi dimasukkan ke dalam erlenmeyer dan ditambahkan $20 \mathrm{~mL}$ larutan $\mathrm{HCl} 37 \%$ sambil dipanaskan di atas hotplate pada suhu $90^{\circ} \mathrm{C}$ selama 3 jam. Perendaman silika tersebut juga dilakukan dengan pengadukan secara berkala. Setelah itu, silika didiamkan hingga suhu turun dan disaring menggunakan kertas saring. Silika kemudian dicuci dengan akuades hingga $\mathrm{pH}$ netral dan dikeringkan menggunakan oven pada suhu $110^{\circ} \mathrm{C}$ selama 3 jam. Analisa kadar silika murni dianalisis menggunakan XRF.

\section{e. Isolasi Silikon dengan Metode Metalotermal Sederhana}

Diambil sampel silika murni kemudian dimasukkan ke dalam cawan porselen. Reduksi dilakukan dengan penambahan bubuk magnesium dengan perbandingan 1:0,8 silika/Mg. Dihomogenkan campuran silika dan magnesium tersebut menggunakan pengaduk. Campuran tersebut kemudian dipanaskan pada suhu $650^{\circ} \mathrm{C}$ selama 3 jam [9]. Diulangi perlakuan pada proses reduksi dengan variasi komposisi pereduksi dengan silika dengan perbandingan $1: 1,5 ; 1: 2$ dan 1:2,5 silika/Mg. Sampel silikon hasil reduksi kemudian dianalisis menggunakan XRD dengan program software Match 3.

\section{f. Pemurnian Silikon}

Sampel hasil dari proses reduksi dimasukkan ke dalam beaker gelas dan ditambahkan $150 \mathrm{~mL} \mathrm{HCl} 2 \mathrm{M}$ lalu dipanaskan pada suhu $80 \mathrm{oC}$ sambil distirer selama 3 jam 
kemudian sampel didinginkan dan disaring menggunakan kertas saring whatman No. 41. Penyaringan menghasilkan padatan dan filtrat. Padatannya dicuci dengan akuades hingga bersifat netral lalu dikeringkan dan ditimbang. Pemurnian ini memiliki tujuan untuk menghilangkan senyawa $\mathrm{MgO}$ [8].

\section{HASIL PENELITIAN}

\section{a. Hasil Isolasi Silika dari Fly Ash}

Hasil analisa XRF Fly ash dari proses preparasi diperoleh data persentase senyawa oksida yang terkandung di dalamnya, persentase terbesar yaitu senyawa silika $38,23 \%, \mathrm{Fe}_{2} \mathrm{O}_{3} 26,77 \%, \quad \mathrm{Al}_{2} \mathrm{O}_{3} 15,37 \%, \mathrm{CaO} 10,79 \%$ dan beberapa senyawa oksida lainnya dengan persentase kecil.

Ekstraksi silika kemudian dilakukan dengan metode presipitasi menggunakan larutan $\mathrm{NaOH}$. Sampel fly ash hasil dari leaching asam dengan $\mathrm{HCl} 3 \%$ kemudian dilarutkan dengan larutan $\mathrm{NaOH} 3 \mathrm{M}$. Persamaan reaksi silika dan $\mathrm{NaOH}$ adalah sebagai berikut [10]:

$$
\mathrm{SiO}_{2}(\mathrm{~s})+2 \mathrm{NaOH}(\mathrm{aq}) \text { e } \quad \mathrm{Na}_{2} \mathrm{SiO}_{3}(\mathrm{aq})+\mathrm{H}_{2} \mathrm{O}(\mathrm{aq})
$$

Hasil reaksi yang diperoleh membentuk natrium silikat $\left(\mathrm{Na}_{2} \mathrm{SiO}_{3}\right)$ dalam wujud liquid tidak berwarna yang bersifat basa. Pengendapan silika dilakukan dengan penambahan $\mathrm{HCl} 1 \mathrm{M}$ hingga larutan berada dalam rentang $\mathrm{pH}$ 6,5-7. Reaksi yang terjadi setelah penambahan $\mathrm{HCl}$ adalah adanya pertukaran ion $\mathrm{Na}^{+}$pada $\mathrm{Na}_{2} \mathrm{SiO}_{3}$ dengan ion $\mathrm{H}^{+}$pada $\mathrm{HCl}$. Reaksinya adalah sebagai berikut :

$$
\mathrm{Na}_{2} \mathrm{SiO}_{3}(\mathrm{aq})+2 \mathrm{HCl}(\mathrm{aq}) \text { ᄅ } \mathrm{H}_{2} \mathrm{SiO}_{3}(\mathrm{~s})+2 \mathrm{NaCl}(\mathrm{aq})[11] \text {. }
$$

Partikel padatan yang diperoleh yaitu asam silikat $\left(\mathrm{H}_{2} \mathrm{SiO}_{3}\right)$ memiliki warna putih. Padatan yang terbentuk ini didiamkan selama 18 jam sehingga membentuk gel. Gel yang diperoleh kemudian disaring dan dicuci dengan akuades panas untuk menghilangkan $\mathrm{NaCl}$. Silika gel yang sudah dicuci kemudian dikeringkan di dalam oven pada suhu $100^{\circ} \mathrm{C}$ selama 4 jam sehingga diperoleh silika dalam bentuk serbuk. Persamaan reaksi yang terjadi pada saat silika gel dikeringkan adalah sebagai berikut

$$
\mathrm{H}_{2} \mathrm{SiO}_{3}(\mathrm{~s}) \text { ᄅ } \quad \mathrm{SiO}_{2}(\mathrm{~s})+\mathrm{H}_{2} \mathrm{O}(\mathrm{g}) \quad \text { [11] }
$$

Menurut hasil XRF fly ash diketahui bahwa kandungan silika sebanyak 38,23\% sehingga jika di dalam 25 gram fly ash proses ekstraksi silika terekstrak semua maka akan diperoleh silika sebanyak 9,557 gram. Massa rata-rata silika yang diperoleh pada penelitian ini adalah sebanyak 2,873 gram dengan rendemen silika 30,06\%. Hasil dari rendemen ekstraksi silika ini lebih besar daripada hasil rendemen ekstraksi silika yang dilakukan dengan tanpa adanya leaching asam menggunakan $\mathrm{HCl} 3 \%$ oleh Nazilah [9] yaitu $14,60 \%$, sehingga dari hasil ini dapat membuktikan bahwa metode leaching asam secara efisien dapat digunakan dalam menghilangkan pengotor. Karakterisasi berikutnya yaitu analisa menggunakan XRF dan diperoleh kadar silika hasil ekstraksi adalah $79,72 \%$ dan kadar silika meningkat kemurniannya menjadi $93,76 \%$ setelah proses pemurnian menggunakan $\mathrm{HCl} 37 \%$.

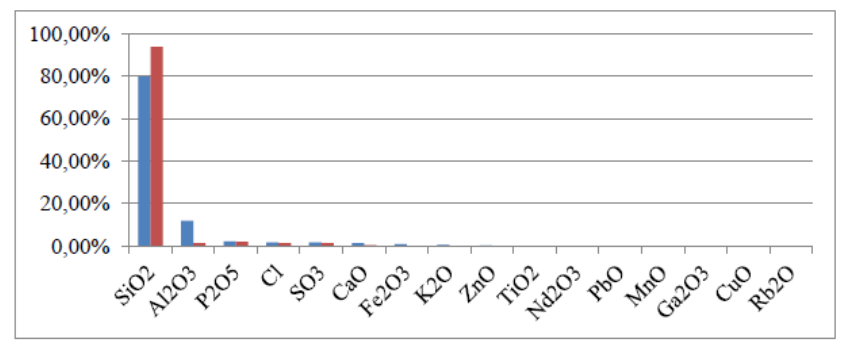

= kadar senyawa sebelum dimurnikan $\square=$ kadar senyawa setelah dimurnikan

Gambar 1. Perbandingan kemurnian silika hasil ekstraksi dan silika murni

\section{b. Hasil Isolasi Silikon}

Isolasi silikon dari silika fly ash batubara pada penelitian ini dilakukan dengan metode metalotermal dengan mereduksi silika menggunakan magnesium dengan variasi massa silika:magnesium berturut-turut adalah 1:0,8 ; $1: 1,5 ; 1: 2$ dan 1:2,5. Adapun persamaan reaksinya adalah sebagai berikut :

$$
\mathrm{SiO}_{2}(\mathrm{~s})+2 \mathrm{Mg}(\mathrm{s}) \text { ᄅ } 2 \mathrm{MgO}(\mathrm{s})+\mathrm{Si}(\mathrm{s}) \ldots \ldots \text { (1) }
$$

Hasil reaksi yang diharapkan pada semua variasi silika:magnesium pada reaksi reduksi adalah sesuai dengan persamaan reaksi 1 , tetapi pada masing-masing jenis variasi menghasilkan produk yang berbeda. Kuantifikasi produk hasil reduksi dihitung menggunakan XRD dengan program software Match 3. Program ini menyajikan nilai semi kuantitatif dengan prinsip membandingkan nilai I/Ic dan sumber standar difratogram yang digunakan berasal dari COD (Crystallography Open Database). Difratogram XRD dari masing-masing produk reaksi reduksi pada variasi silika:magnesium berturut-turut adalah 1:0,8 ; 1:1,5 ; 1:2 dan 1:2,5 ditunjukkan pada gambar 2. Difratogramdifratogram yang diperoleh dapat memberikan informasi tentang komponen kimia dengan nilai kuantifikasinya yang dihasilkan pada setiap produk reaksi reduksi semua variasi massa silika:magnesium. Tabel 1 merupakan tabel yang menunjukkan nilai kuantifikasi produk hasil reaksi reduksi.

Tabel 1. Kuantifikasi produk hasil reaksi reduksi menggunakan XRD

\begin{tabular}{lcccc}
\hline No. & $\begin{array}{c}\text { Variasi Massa } \\
\text { silika:magnesium }\end{array}$ & $\mathrm{MgO}$ & $\mathrm{SiO}_{2}$ & $\mathrm{Si}$ \\
\cline { 3 - 5 } 1. & $1: 0,8$ & 88.1 & 7.1 & 4.8 \\
2. & $1: 1,5$ & 94.1 & 5.9 & - \\
3. & $1: 2$ & 93.9 & 6.1 & - \\
4. & $1: 2,5$ & 97.6 & 2.4 & - \\
\hline
\end{tabular}




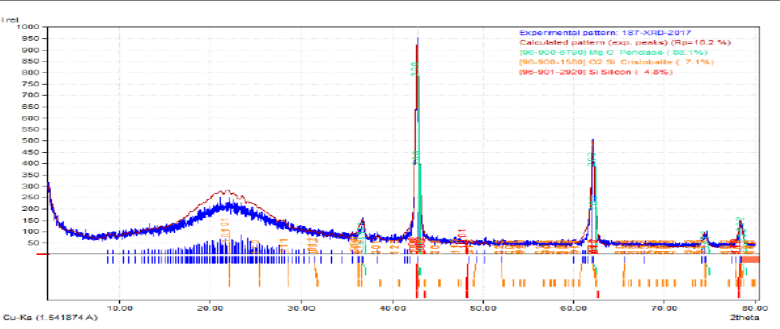

(a)
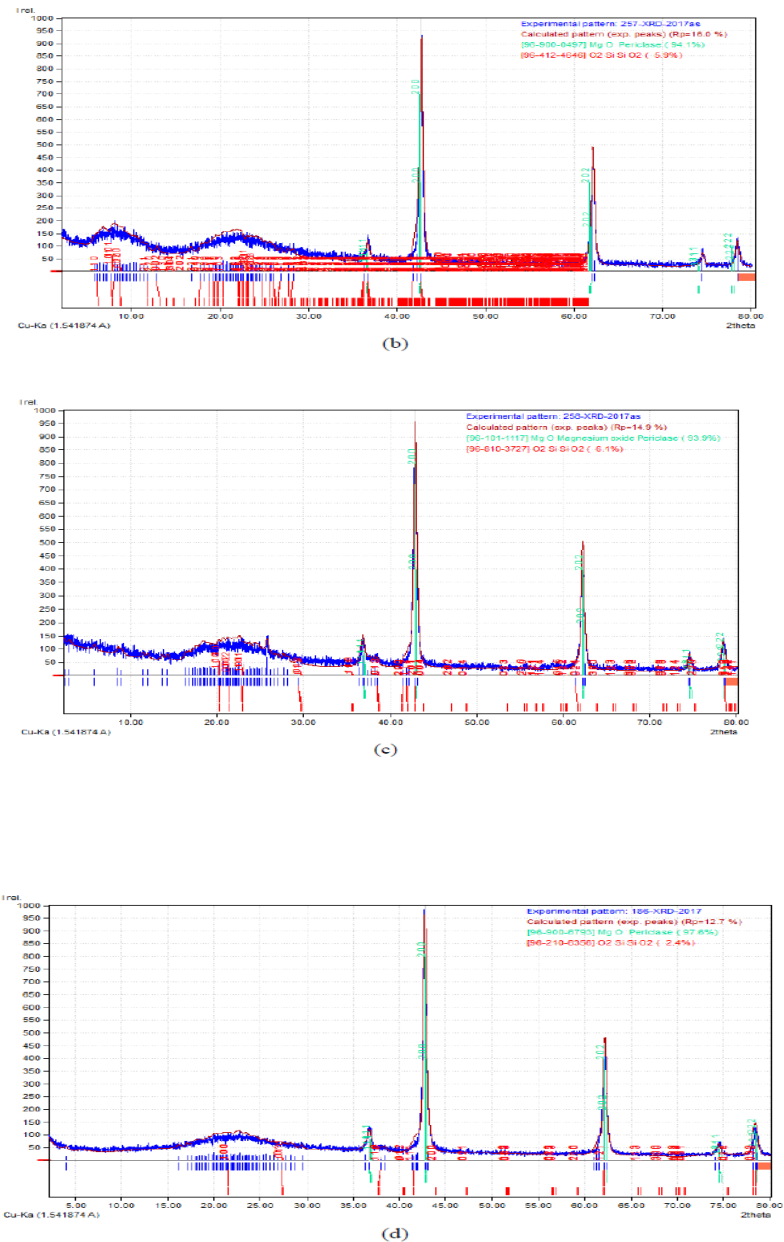

Gambar 2. Difratogram produk reaksi reduksi silika : magnesium a (1:0,8), b(1:1,5), c(1:2) dan d(1:2,5)

Hasil produk reaksi reduksi pada variasi silika:magnesium 1:0,8 menunjukkan adanya silikon muncul pada puncak 2 theta di titik $42.77^{\circ}, 48.43^{\circ}$ dan $78.39^{\circ}$ dengan sistem kristal heksagonal. Silikon yang diperoleh memiliki persentase yang kecil, hal ini kemungkinan disebabkan karena pada saat reaksi reduksi terjadi, logam magnesium cenderung bereaksi terlebih dahulu dengan oksigen yang berada di udara bebas sehingga proses untuk mereduksi $\mathrm{SiO}_{2}$ tidak dapat berjalan secara sempurna. Peristiwa ini terjadi karena metode yang digunakan adalah metode metalotermal sederhana dengan tanpa adanya reaktor atau gas argon yang dapat meminimalisir adanya oksigen bebas. Namun hal ini membuktikan bahwa metode metalotermal sederhana juga dapat digunakan dalam proses reduksi karena juga dapat menghasilkan silikon meskipun kurang efektif.

Karakterisasi menggunakan XRD keseluruhan terhadap semua variasi massa silika:magnesium menunjukkan bahwa silikon yang dihasilkan hanya diperoleh pada variasi silika:magnesium 1:0,8. Hal ini terjadi kemungkinan karena silikon pada variasi massa silika:magnesium yang lain memang tidak terbentuk atau kemungkinan terbentuk senyawa lain. Persenyawaan lain yang dimaksud adalah berupa senyawa $\mathrm{Mg}_{2} \mathrm{SiO}_{4}, \mathrm{Mg}_{2} \mathrm{Si}$ atau $\mathrm{MgSiO}_{3}$. Kemungkinan terbentuknya beberapa persenyawaan silikon tersebut mengacu pada karakterisasi XRD pada hasil pemurnian (Gambar 3) yang menunjukkan adanya pembentukan $\mathrm{Mg}_{2} \mathrm{SiO}_{4}, \mathrm{Mg}_{2} \mathrm{Si}$ dan $\mathrm{MgSiO}_{3}$, sehingga silikon yang optimum terbentuk pada variasi silika:magnesium 1:0,8. Hal ini terjadi karena pada variasi 
silika:magnesium 1:0,8 merupakan perbandingan stoikiometri, sedangkan pada variasi silika:magnesium yang lainnya mengalami reaksi yang tidak terkontrol sehingga menghasilkan senyawa $\mathrm{MgO}$ sebagai produk mayor dan kemungkinan beberapa senyawa lainnya dalam jumlah yang sangat berlebih sehingga kemungkinan menjadi penyebab silikon tidak terbentuk. Kuantifikasi senyawa lainnya yang terbentuk adalah $\mathrm{MgO}$ (periclase) dengan sistem kristal kubik pada semua produk dari variasi silika:magnesium. Sistem kristal senyawa silika yang terbentuk pada semua produk hasil reaksi reduksi untuk semua variasi massa silika:magnesium $1: 0,8 ; 1: 1,5 ; 1: 2$ dan 1:2,5 berturut-turut adalah tetragonal, tetragonal, heksagonal dan trigonal.

Karakterisasi kedua yaitu menggunakan XRF. Tabel 2 menunjukkan hasil analisa XRF menggunakan standar oksida dan tabel 3 menunjukkan hasil analisa XRF menggunakan standar single element.

Tabel 2. Kuantifikasi produk reaksi reduksi (oksida) pada analisa XRF

\begin{tabular}{|c|c|c|c|c|}
\hline \multirow{2}{*}{$\begin{array}{l}\text { Produk reduksi } \\
\text { (oksida) (\%) }\end{array}$} & \multicolumn{4}{|c|}{ Perbandingan massa $\mathrm{SiO}_{2: \mathrm{Mg}}$} \\
\hline & $1: 0,8$ & $1: 1,5$ & $1: 2$ & $1: 2,5$ \\
\hline $\mathrm{SiO}_{2}$ & 78,00 & 67,17 & 61,49 & 59,47 \\
\hline $\mathrm{MgO}$ & 16,55 & 26,78 & 32,72 & 35,79 \\
\hline $\mathrm{P}_{2} \mathrm{O}_{5}$ & 1,70 & 1,88 & 2,18 & 1,63 \\
\hline $\mathrm{SO}_{3}$ & 1,18 & 1,29 & 1,53 & 1,28 \\
\hline $\mathrm{Cl}$ & 1,16 & 1,15 & 1,32 & 1,17 \\
\hline $\mathrm{Al}_{2} \mathrm{O}_{3}$ & 0,78 & 1,07 & . & . \\
\hline $\mathrm{CaO}$ & 0,44 & 0,44 & 0,49 & 0,41 \\
\hline $\mathrm{Fe}_{2} \mathrm{O}_{3}$ & 0,13 & 0,09 & 0,12 & 0,13 \\
\hline $\mathrm{ZnO}$ & 0,02 & 0,03 & 0,03 & 0,02 \\
\hline $\mathrm{MnO}$ & . & 0,02 & 0,01 & 0,01 \\
\hline $\mathrm{SnO}_{2}$ & 0,01 & - & - & . \\
\hline $\mathrm{CeO}_{2}$ & - & 0,02 & - & ${ }^{-}$ \\
\hline $\mathrm{Cr}_{2} \mathrm{O}_{3}$ & - & - & - & 0,02 \\
\hline $\mathrm{Nd}_{2} \mathrm{O}_{3}$ & - & - & 0,04 & - \\
\hline
\end{tabular}

Hasil karakterisasi menggunakan XRF pada produk reaksi reduksi variasi pertama yaitu silika:magnesium 1:0,8 menunjukkan bahwa kandungan unsur silikon secara keseluruhan yaitu $71,74 \%$ yang ditunjukkan pada Tabel 3 dan persentase silikon dalam bentuk senyawa $\mathrm{SiO}_{2}$ adalah $36,46 \%$, namun selisih hasil nilai kuantifikasi keduanya tersebut tidak dapat dijadikan sebagai acuan tentang jumlah kandungan unsur silikon yang diperoleh dalam bentuk single element atau silikon dalam bentuk murni karena kemungkinan di dalam jumlah tersebut juga terdapat silikon dalam bentuk persenyawaan lain yaitu silikon dalam senyawa $\mathrm{SiO}_{2}, \mathrm{Mg}_{2} \mathrm{Si}, \mathrm{Mg}_{2} \mathrm{SiO}_{4}$ atau $\mathrm{MgSiO}_{3}$, sehingga hasil analisa XRF tidak dapat memberikan kepastian informasi mengenai hasil kuantifikasi silikon murni yang dihasilkan dalam proses reaksi reduksi. Jenis hasil analisa XRF yang sama juga diperoleh pada jenis reaksi reduksi kedua, ketiga dan keempat berturut-turut memiliki jumlah persentase silikon secara keseluruhan adalah 69,47\%, $63,60 \%$ dan $61,51 \%$ yang ditunjukkan pada Tabel 4.10 , sedangkan persentase silikon dalam bentuk senyawa $\mathrm{SiO}_{2}$ pada jenis reaksi reduksi kedua, ketiga dan keempat masing-masing adalah $31,40 \%, 28,74 \%$ dan $27,80 \%$. Ketiga jenis reaksi tersebut juga menghasilkan selisih nilai antara jumlah silikon dalam bentuk single element dan jumlah silikon dalam senyawa $\mathrm{SiO}_{2}$, namun hal ini tidak dapat dijadikan acuan tentang nilai persentase silikon murni yang dihasilkan karena masih terdapat kemungkinan di dalam jumlah sisa tersebut terdapat persenyawaan silikon yang lain.

Tabel 3. Kuantifikasi produk reaksi reduksi (single element) pada analisa XRF

\begin{tabular}{|l|l|l|l|l|}
\hline \multirow{2}{*}{$\begin{array}{l}\text { Preduk, reduksi } \\
\text { (single element) } \\
\text { (\%) }\end{array}$} & \multicolumn{4}{|c|}{ Perbandingan massa SiO :Mg } \\
\cline { 2 - 5 } & $1: 0,8$ & $1: 1,5$ & $1: 2$ & $1: 2,5$ \\
\hline $\mathrm{Si}$ & 71,74 & 69,47 & 63,60 & 61,51 \\
$\mathrm{Mg}$ & 16,20 & 20,50 & 25,05 & 27,40 \\
$\mathrm{P}$ & 2,75 & 2,17 & 2,52 & 1,88 \\
$\mathrm{~S}$ & 1,75 & 1,74 & 2,06 & 1,73 \\
$\mathrm{Cl}$ & 4,81 & 4,18 & 4,80 & 4,25 \\
& 1,66 & 1,01 & - & - \\
$\mathrm{Al}$ & 0,56 & 0,54 & 0,60 & 0,41 \\
$\mathrm{Ca}$ & 0,21 & 0,21 & 0,28 & 0,13 \\
$\mathrm{Fe}$ & 0,07 & 0,08 & 0,08 & 0,02 \\
$\mathrm{Zn}$ & 0,01 & - & - & 0,01 \\
$\mathrm{Mgn}$ & 0,02 & - & - & - \\
$\mathrm{Sn}$ & 0,02 & 0,01 & 0,01 & 0,01 \\
$\mathrm{Zr}$ & 0,02 & 0,01 & 0,01 & 0,01 \\
$\mathrm{Br}$ & 0,03 & - & - & - \\
$\mathrm{V}$ & 0,03 & 0,02 & 0,02 & - \\
$\mathrm{Bi}$ & 0,03 & - & - & - \\
$\mathrm{Ii}$ & 0,02 & 0,01 & 0,01 & - \\
$\mathrm{Au}$ & 0,01 & - & - & - \\
$\mathrm{Cd}$ & 0,01 & - & - & - \\
$\mathrm{U}$ & 0,01 & - & - & - \\
$\mathrm{Se}$ & - & 0,01 & 0,01 & - \\
$\mathrm{Cu}$ & - & - & - & 0,01 \\
$\mathrm{Cr}$ & - & - & - & 0,02 \\
\hline
\end{tabular}

\section{c. Hasil Pemurnian silikon}

Pemurnian silikon dilakukan dengan menggunakan perbandingan silika:magnesium yaitu 1:0,8 dan berhasil meningkatkan persentase kemurnian silikon yang dihasilkan dari $4,8 \%$ menjadi $5,6 \%$. Tahap pemurnian silikon dilakukan dengan tujuan untuk menghilangkan pengotor berupa senyawa $\mathrm{MgO}$, dan pada penelitian ini pemurnian menggunakan $\mathrm{HCl} 2 \mathrm{M}$ berhasil menurunkan persentase kadar senyawa $\mathrm{MgO}$. Senyawa $\mathrm{MgO}$ sebelum pemurnian berjumlah $88,1 \%$ dan setelah pemurnian menurun menjadi $5,5 \%$. Hasil XRD pada proses pemurnian ini juga menunjukkan bahwa senyawa $\mathrm{Mg}_{2} \mathrm{SiO}_{4}, \mathrm{Mg}_{2} \mathrm{Si}$ dan $\mathrm{MgSiO}_{3}$ juga terbentuk pada produk reaksi. Gambar 3 menunjukkan persentase senyawa yang terkandung di dalam produk hasil pemurnian silikon

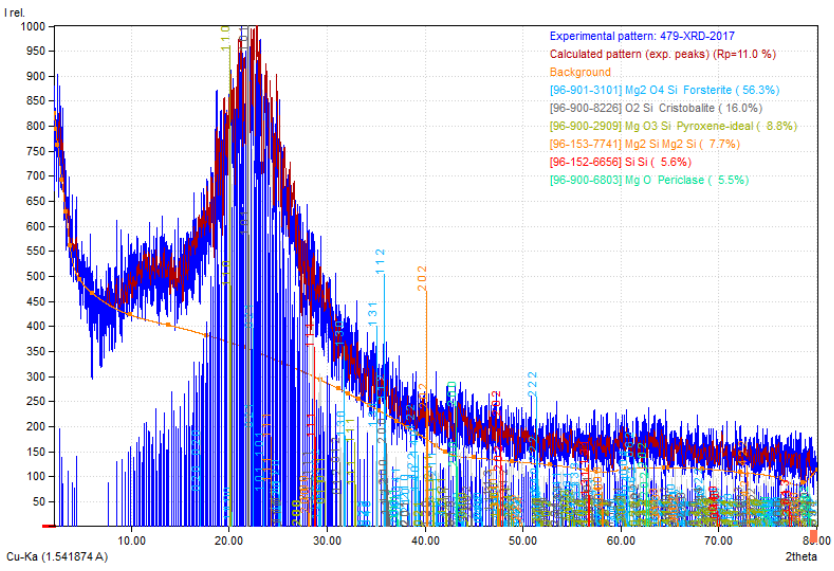

Gambar 3. Difratogram produk pemurnian silikon 
Pembentukan $\mathrm{Mg}_{2} \mathrm{SiO}_{4}$ terjadi karena adanya reaksi antara $\mathrm{MgO}$ pada permukaan $\mathrm{SiO}_{2}$ membentuk senyawa enstatite $\left(\mathrm{MgSiO}_{3}\right)$ sebagai fase intermediet sehingga akhirnya membentuk forsterite $\left(\mathrm{Mg}_{2} \mathrm{SiO}_{4}\right)$. Reaksinya adalah sebagai berikut

$\mathrm{SiO}_{2}(\mathrm{~s})+2 \mathrm{MgO}(\mathrm{s})$ ᄅ $\mathrm{MgSiO}_{3}(\mathrm{~s}) \ldots(2)$

(fasa intermediet)

$\mathrm{MgSiO}_{3}(\mathrm{~s})+\mathrm{MgO}(\mathrm{s})^{\text {e }} \mathrm{Mg}_{2} \mathrm{SiO}_{4}(\mathrm{~s}) \ldots .(3)$

(forsterite)

[12].

Senyawa lain yang terbentuk juga adalah $\mathrm{Mg}_{2} \mathrm{Si}$, Adapun reaksi pembentukan $\mathrm{Mg}_{2} \mathrm{Si}$ adalah sebagai berikut

$$
\begin{aligned}
& 3 \mathrm{SiO}_{2}(\mathrm{~s})+2 \mathrm{Mg}(\mathrm{g}){ }^{\text {ㄹ }} 2 \mathrm{MgSiO}_{3}(\mathrm{~s})+\mathrm{Si}(\mathrm{s}) \ldots .(4) \\
& 4 \mathrm{MgSiO}_{3}(\mathrm{~s})+2 \mathrm{Mg}(\mathrm{g}) \text { ᄅ } 3 \mathrm{Mg}_{2} \mathrm{SiO}_{4}(\mathrm{~s})+\mathrm{Si}(\mathrm{s}) \text {....(5) } \\
& \mathrm{Mg}_{2} \mathrm{SiO}_{4}(\mathrm{~s})+2 \mathrm{Mg}(\mathrm{g})^{\text {e }} \quad 4 \mathrm{MgO}(\mathrm{s})+\mathrm{Si}(\mathrm{s}) \ldots .(6) \\
& \mathrm{Si}(\mathrm{s})+2 \mathrm{Mg}(\mathrm{s}) \text { ᄅ } \mathrm{Mg}_{2} \mathrm{Si} \ldots(7)
\end{aligned}
$$

[4]

\section{KESIMPULAN}

Kesimpulan yang didapat dari penelitian ini adalah kadar silika hasil ekstraksi dari fly ash batubara yaitu 79,72\% dan meningkat menjadi $93,76 \%$ setelah dilakukan pemurnian. Komposisi rasio silika dan magnesium yang menghasilkan silikon maksimum dalam proses isolasi silikon dari fly ash adalah 1:0,8, serta kadar silikon hasil isolasi dari fly ash sebelum dan setelah pemurnian berturut-turut adalah 4,8\% dan $5,6 \%$.

Saran dari penelitian ini adalah proses reaksi reduksi silika dari fly ash batubara harus dilakukan dengan menggunakan reaktor untuk menghindari oksigen di udara, reduktor silika yang berasal dari fly ash dapat menggunakan karbon dalam reaksi reduksi untuk mendapatkan silikon dan pemurnian silikon dapat menggunakan metode hidrometalurgi.

\section{DAFTAR PUSTAKA}

[1] Okutani, T. 2009. Utilization of silica in rice hulls as raw materials for silicon semiconductors. Journal of Metals, Materials And Minerals In Japan.19 (2): 5159.

[2] Retnosari, A. 2013. Ekstraksi dan Penentuan Kadar Silika $\left(\mathrm{SiO}_{2}\right)$ Hasil Ekstraksi dari Abu Terbang (Fly Ash) Batubara. Skripsi. Jember: Kimia FMIPA UNEJ.

[3] Fatony, M. H. A. 2015. Ekstraksi Silika dari Fly ash Batubara (Studi Pengaruh Variasi Waktu Ekstraksi, Jenis Asam dan pH). Skripsi. Jember: Kimia FMIPA UNEJ.

[4] Banerjee, H.D., S Sen. H N Acharya. 1982. Investigation on the production of silicon from rice husks by the magnesium method. Material Science and Engineering. 52(5):173 - 179.

[5] Grjotheim, K., K. Matiasovsky dan P. and P. Fellner. 1973. Some aspects of the electrolytic preparation of silicon alloys. Norway : Chem. Zvesti. 27(2) : 165171.

[6] Sadique, S.E. 2010. Production and Purification of Silicon by Magnesiothermic Reduction of Silica Fume. Thesis. Toronto : Department of Materials
Science and Engineering University of Toronto.

[7] Adjiantoro B dan E. Mabruri. 2010. Proses pemurnian silikon tingkat metalurgi dengan menggunakan metoda pelarutan kimia. Majalah Metalurgi. 5:71-78.

[8] Sitorus, S.M. 2014. Peningkatan Kemurnian Silikon Dari Pasir Kuarsa Secara Magnesiotermik Dengan Variasi Waktu. Skripsi. Medan: Departemen Kimia Fakultas Matematika Dan Ilmu Pengetahuan Alam Universitas Sumatera Utara.

[9] Nazilah, A. 2015. Isolasi Silikon (Si) Dari Abu Terbang (Fly Ash) Batu Bara Dengan Metode Metalotermal. Skripsi. Jember : Jurusan Kimia Fakultas Matematika Dan Ilmu Pengetahuan Alam Universitas Jember.

[10] Svehla G. 1985. Vogel Bagian II Buku Teks Analisis Anorganik Kualitatif Makro dan Semimikro Edisi ke lima. Jakarta : PT. Kalman Media Pustaka.

[11] Bakri, R. 2008. Kaolin sebagai sumber $\mathrm{SiO}_{2}$ untuk pembuatan katalis $\mathrm{Ni} / \mathrm{SiO}_{2}$ : karakterisasi dan uji katalis pada hidrogenasi benzena menjadi sikloheksana. Jurnal sains.12(1): 37-42.

[12] Ramesh, S., A.Yaghoubi, KY. Sara Lee, KM.Christopher Chin, J. Purbolaksono dan M. Hamdi, M.A. Hassan. 2013. Nanocrystalline forsterite for biomedical applications : Synthesis, microstructure and mechanical properties. Journal of the mechanical behavior of biomedical materials. 25 : 63-69.

[13] Davis, S. C. 2013. Stress and Microstructural Evolution During Shape-Preserving Silica Magnesiothermic Reduction. Disertasi. Amerika Serikat : Georgia Institute of Technology. 